\title{
Marketing Brexit: An exploratory study of young voter engagement in relation to the $\mathrm{EU}$ Referendum
}

\begin{abstract}
This paper presents an exploratory study of young voter engagement in relation to the EU referendum - a democratic vote on the United Kingdom's membership of the European Union. Using the marketing concept of engagement we examine how young voters engaged cognitively, emotionally and behaviourally with the referendum and its associated campaigns. A mixed method study combining multiple-phase questionnaires, longitudinal social network analysis of Twitter and sentiment analysis provide an exploratory account of young voter engagement. The findings reveal that young voter engagement is multi-faceted and varies enormously across our sample, particularly for behavioural engagement online. We subsequently question the analytical relevance of the engagement construct for political marketing before then developing a typology to segment young voters according to the variance and extent of their specific engagement profile. We conclude the paper by presenting an agenda for future research on young voter engagement.
\end{abstract}

\section{Keywords}

Young Voter, Engagement, Political Marketing, Social Media 


\section{Introduction}

Young people were the focus of widespread media attention before and after the UK voted to leave the European Union. In addition, young people were often characterised as alienated, mistrustful and disinterested with political systems (Barrett and Brunton-Smith 2014; Dermody and Hanmer-Lloyd 2004; Macnamara et al. 2012). Indeed, young people were less politically engaged than every other age group yet given their perceived preference for membership in the EU compared to older generations, their absence from the vote may have been the deciding factor. But this raises an important question: is voter turnout the singular measure of engagement? Further, this has led a variety of authors (Boonen et al. 2014; Fieldhouse et al. 2007; Henn et al. 2002; Henn et al. 2005; Wagner et al. 2012) to call for further research addressing young voter participation and associated confounding variables. The study reported in this article is designed with two key aims to a) explore how young people engaged with the EU Referendum event on $23^{\text {rd }}$ June 2016; and b) to contribute more broadly to a general theory of political event engagement that can help hypothesise how young voters differ and what can be done to activate their interest through the marketing of political events.

In the first section we review recent work in the discipline of political marketing which has called for further investigation into how young voters become (dis)engaged. In the second section we review the increasingly influential concept of engagement in the marketing-specific literature and discuss conflicting definitions before describing a three-dimensional account of engagement that can inform empirical study. The third section outlines the research design of our study including the adoption of a mixed-method approach, justification and development of the research methods, explanation and critical discussion of the sampling framework and culminates with reference to the analytical process. The results of two research questions are then discussed in the fourth section. The discussion of the first research question presents a detailed overview of the variance and extent of young voter engagement in relation to the EU referendum. The second question attempts to contribute to a general theory of political engagement by developing a typology to classify and segment young voters according to specific engagement profiles. In the fifth and final section of the article, we conclude by presenting an agenda for future research on political event engagement.

\section{Political Marketing}

Political marketing represents a sophisticated area of study, "beyond the black arts of propaganda" (Harris and Lock 2010:297) and amalgamates theories, concepts, tools and frameworks transferred from diverse disciplines such as commercial marketing and political science (Harris and Lock 2010; Henneberg and O'shaughnessy 2007; Hughes and Dann 2009; O'Cass 2001; Speed et al. 2015). More specifically, political marketing has been defined as " $a$ set of activities, processes or political institutions used by political organisations, candidates and individuals to create, communicate, deliver and exchange promises of value with voterconsumers, political party stakeholders and society at large" (Hughes and Dann 2009:244). According to Simons (2016:4) in "recent years there has been an increased level of voter volatility which has been matched by an interest in understanding electoral behaviour". Existing research within political marketing tends to focus on two broad perspectives namely behavioural and managerial (O'Cass and Nataraajan 2003). Behavioural political marketing includes aspects such as voter behaviour, engagement, participation whereas managerial political marketing tends to focus on the development and management of political parties, political brands, targeted campaigns, elections and the creation of political communications 
designed to appeal to desired segments (Hughes and Dann 2009; Needham and Smith 2015; O'Cass and Nataraajan 2003; O'Cass and Voola 2011; Simons 2016). However, despite progress made within political marketing, many gaps remain (Needham and Smith 2015; Nielsen 2016; O'Cass and Voola 2011). There are explicit calls for more empirical research of voter-centric perspectives such as how young voters engage and participate in the political process and how engagement develops through time (Gibson and Cantijoch 2013; Lilleker and Koc-Michalska 2017; Macnamara et al. 2012).

As a dedicated area of thought in its own right, political marketing can only progress it if continues to develop new concepts or reapply advanced theories and frameworks (O'Shaughnessy and Henneberg 2007; Smith and Speed 2011; Speed et al. 2015). This study will address the limited number of theoretical frameworks in this area of study, with the aim to assist political stakeholders in the practical study of young voter engagement. The primary aim of the research is to consider how engagement data might be used to profile and segment young voters to improve targeting. Research in this area is increasingly pertinent due to the "growing democratic deficit identified in a number of contemporary societies" including the growing sense of mistrust, alienation and disengagement of young people and politics (Macnamara et al. 2012:624). In the following two sections we describe the engagement construct as discussed in the politics and marketing literature respectively before describing a working definition of political event engagement.

\section{Young Voter Engagement and Participation}

Previous research suggests that "young people are the most disengaged of all the electoral segments in Britain" and often feel alienated with politics (Dermody et al. 2010:422; Nickerson 2006). Young people [18-25 years] are less likely to vote, hold negative attitudes towards the electoral process and are less likely to be involved in conventional political activities such as joining and supporting political parties (Barrett and Brunton-Smith 2014; Macnamara et al. 2012). In addition, young people are widely seen as disenchanted with politics, distrustful and cynical of political institutions and have limited identification with political parties (Dermody and Hanmer-Lloyd 2004; Dermody et al. 2010). Young people are described as being alienated, cynical and disengaged with voting, yet also being interested and knowledgeable about political processes such as elections and voting (Dermody et al. 2010; Macnamara et al. 2012; Nickerson 2006). This contradiction suggests young people can be distrustful and critical about politics despite having a strong sense of "personal efficacy', "where they believe they are knowledgeable about political issues and are interested in the election" (Dermody et al. 2010:430). Improved personal efficacy may counteract cynicism and distrust of political voting, which can lead to a deeper sense of personal involvement and engagement (Dermody et al. 2010; De Vreese 2005; Pinkleton and Austin 2002), but it is also clear that this is not a simple linear relationship. Few existing studies consider whether the type of election [referendum or national elections for example] has an impact on young voter engagement and participation (Quinlan et al.2015). The majority of studies in this area tend to focus on national elections rather than intermittent elections like referenda. Insight in this area is restricted further by the common failure to provide robust conceptualisations of what political engagement actually is.

The terms voter 'engagement' and 'behaviour' are often used interchangeably without clear definitions (Dermody et al. 2010; De Vreese 2005; Mann and Mayhew 2015; Pinkleton and Austin 2002). Similarly, 'engagement' has also become synonymous with 'participation' or voting in elections (Bromley et al. 2001; Ekman and Amna 2012; Ikeda et al. 2008; Macnamara et al. 2012; Nickerson 2006) and this ambiguity broadens rather than focuses the debate. 
However, authors such as Bromley et al. (2001), Barrett and Brunton-Smith (2014), Ekman and Amna (2012) have attempted to develop some insight into the conceptualisation of engagement-participation. For example, participation can be divided into conventional and non-conventional 'behavioural' actions, such as voting, election campaigning, joining a political party [conventional], and signing petitions and participating in political demonstrations, and communicating with politicians [non-conventional] (Barrett and BruntonSmith 2014). Nevertheless, Barrett and Brunton-Smith (2014) fail to acknowledge the interchangeable nature of conventional and non-conventional forms. Similarly, engagement can be considered through other different 'cognitive-emotive' manifestations, for instance paying attention to political communications such as newspapers, television, radio, or social media, following political affairs, understanding political processes and institutions and having feelings about political matters, or discussing politics with other people (Barrett and BruntonSmith 2014). Again, Barrett and Brunton-Smith (2014) fail to outline the interchangeable nature of engagement factors or explicitly explain that these forms appear to be cognitiveemotive characteristics. This feeds into the wider debate as many of the existing studies fail to explain how the conceptualisations of behavioural participation and cognitive-emotive engagement were developed (Bromley et al. 2001; Barrett and Brunton-Smith 2014; Ekman and Amna 2012). Therefore, future research should aim to provide further insight into this area of study.

Recent attempts to utilise digital platforms to mobilise young voters and strengthen engagement have had some success at the ballot box (Koc-Michalska and Lilleker 2017; Lilleker and Koc-Michalska 2017; Macnamara et al. 2012; Mann and Mayhew 2015). This seems logical given the fact that young people are avid users of digital tools and platforms (Macnamara et al. 2012). Indeed, studies of political engagement seem more likely to provide holistic insight into young voters' lives if they consider engagement across multiple marketing campaigns and channels, such as social media where large tranches of political discussion now occur. However, we return to the same issue identified earlier that existing studies fail to conceptualise engagement beyond ambigiuous definitions (Koc-Michalska and Lilleker 2017; Lilleker and Koc-Michalska 2017; Macnamara et al. 2012; Mann and Mayhew 2015). Nevertheless, most research in this area suggests voter engagement is linked to future habitual voting patterns (Barrett and Brunton-Smith 2014; Gorecki 2013; Nickerson 2006). We suggest therefore that, research devoted to understanding young voter engagement and participation deserves attention, as this will provide pragmatic solutions to disengagement, and allow for the development of long-term strategies to mobilise the young electorate (Lilleker and KocMichalska 2017; Macnamara et al. 2012; Mann and Mayhew 2015; Nickerson 2006; Thananithichot 2012). Despite some progress made in young voter engagement-participation in political marketing research, the topic area remains complex, debated and differs from context to context (Barrett and Brunton-Smith 2014; Dermody et al. 2010; Lilleker and KocMichalska 2017; Thananithichot 2012). In order to develop a conceptual understanding of young voter engagement, we believe there is a need to step back and revisit the 'engagement' literature more broadly within the marketing discipline.

\section{Engagement in the marketing literature}

The 'engagement' concept is not only complex and debated in marketing but across other disciplines and subject areas. For example, 'engagement' has been conceptualised in other fields of social science such as organisational behaviour (Bowden 2009; Dessart et al. 2016) and management (Sashi 2012), where there is also agreement that engagement goes beyond any simplistic behavioural element. Sashi (2012) similarly suggests both affective and cognitive are necessities for customer 'engagement'. In the same vein, Bowden (2009) 
proposed 'engagement' as a concept that includes cognitive and emotional aspects. Similar debate seems to exist in the marketing literature. In much of the pioneering work examining 'customer engagement' (Brodie et al. 2011; Van Doorn et al. 2010; Hollebeek 2011) the main focus has been on defining the concept and distinguishing it from other similar concepts such as involvement and interaction. Central to all of these works is the claim that 'engagement' is a multi-dimensional phenomena and that cognitive and/or affective dimensions of engagement make this concept different from mainly behavioural concepts (Mollen and Wilson 2010; Bowden 2009). Although there is still debate on the forms of dimensionality, it is generally accepted among scholars that customer engagement includes cognitive, affective and behavioural dimensions (Brodie et al. 2011; Hollebeek et al. 2014; Dessart et al. 2016). Table (1) presents a summary of recent empirical research that conceptualises engagement in the marketing literature and the respective definitions and dimensions utilised:

Table 1: Conceptualisations of engagement in the marketing literature for empirical study

\begin{tabular}{|c|c|c|c|c|}
\hline Author(s) & The Construct & Definition & Dimensionality & The context \\
\hline $\begin{array}{l}\text { Baldus et al. } \\
2015\end{array}$ & $\begin{array}{l}\text { Online Brand } \\
\text { Community } \\
\text { Engagement }\end{array}$ & $\begin{array}{l}\text { Online brand community } \\
\text { engagement is the compelling, } \\
\text { intrinsic motivations to continue } \\
\text { interacting with an online brand } \\
\text { community }\end{array}$ & $\begin{array}{l}11 \text { independent } \\
\text { motivations }\end{array}$ & $\begin{array}{l}\text { Online brand } \\
\text { community }\end{array}$ \\
\hline $\begin{array}{l}\text { Calder et al. } \\
(2016)\end{array}$ & $\begin{array}{l}\text { Customer } \\
\text { engagement }\end{array}$ & $\begin{array}{l}\text { Engagement is a multilevel construct } \\
\text { that emerges from the thoughts and } \\
\text { feelings about one or more rich } \\
\text { experiences involved in reaching } \\
\text { a personal goal. }\end{array}$ & $\begin{array}{l}3 \text { dimensions: } \\
\text { - Affective, } \\
\text { - Cognitive } \\
\text { - Behavioural }\end{array}$ & $\begin{array}{l}\text { live jazz music, } \\
\text { Newspapers, } \\
\text { Television } \\
\text { programming }\end{array}$ \\
\hline $\begin{array}{l}\text { Dessart et al. } \\
(2016)\end{array}$ & $\begin{array}{l}\text { Consumer } \\
\text { engagement }\end{array}$ & $\begin{array}{l}\text { 'the state that reflects consumers' } \\
\text { individual dispositions toward } \\
\text { engagement foci, which are } \\
\text { context-specific. Engagement is } \\
\text { expressed through varying levels of } \\
\text { affective, cognitive, and behavioural } \\
\text { manifestations that go beyond } \\
\text { exchange situations'. }\end{array}$ & $\begin{array}{l}3 \text { dimensions: } \\
\text { - Affective, } \\
\text { - Cognitive } \\
\text { - Behavioural }\end{array}$ & $\begin{array}{l}\text { Online brand } \\
\text { Community }\end{array}$ \\
\hline $\begin{array}{l}\text { Hollebeek et al. } \\
\text { (2014) }\end{array}$ & $\begin{array}{l}\text { Consumer } \\
\text { Brand } \\
\text { Engagement } \\
\text { in Social Media }\end{array}$ & $\begin{array}{l}\text { A consumer's positively valenced brand } \\
\text {-related cognitive, emotional and } \\
\text { behavioral activity during or related } \\
\text { to focal consumer/brand interactions. }\end{array}$ & $\begin{array}{l}3 \text { dimensions: } \\
\text { - Affective, } \\
\text { - Cognitive } \\
\text { - Behavioural }\end{array}$ & $\begin{array}{l}\text { Social Network } \\
\text { Sites }\end{array}$ \\
\hline
\end{tabular}

Cognitive engagement as defined by Dessart et al. (2016: 408) is "a set of enduring and active mental states experienced by the consumer". Specifically cognitive engagement is illustrated by thought processing and elaboration towards the object of engagement and thus incorporates a person's intentional states, opinion and knowledge. Affective engagement relates to words such as 'bond', 'care' and 'emotion' when consumers speak about a brand (Dessart et al. 2016). Data for affective engagement can be gleaned by listening to the way people speak about an object and examining verbatim for the presence of cues in the language chosen, for example the emotional valence of words. Behavioural engagement is defined by Van Doorn et al. (2010:255) as "behavioural manifestation toward a brand or firm, beyond purchase, resulting from motivational drivers", in a political context this would mean behaviours beyond merely voting.

Engagement behaviours manifest in the political context in a number of different forms including both conventional forms which involve electoral processes and non-conventional forms which occur outside electoral processes. Following work that has examined customer engagement behaviours online (Schivinski et al. 2016; Poorrezaei 2016) we suggest there are also at least three different forms of behavioural engagement that could be observed through 
use of social media, these are: 1) broadcasting: discussing explicitly political topics in public; 2) subscription - deliberately selecting and following political actors online in order to receive direct news updates; and 3) dialogue - explicitly sending public messages to political actors in order to support or persuade.

The current study modifies Bowden et al.'s (2017) definition of engagement dimensions and proposes a definition specifically for voter engagement. Table (2) shows the working definitions of this study.

Table 2: Working definition for engagement dimensions

Engagement Dimensions

\begin{tabular}{|c|c|c|c|}
\hline & Cognitive & Affective & Behavioural \\
\hline $\begin{array}{l}\text { olitical event } \\
\text { s } \\
\text { ocal object }\end{array}$ & $\begin{array}{l}\text { An individual voter's degree } \\
\text { of political event related } \\
\text { thought processing and } \\
\text { elaboration }\end{array}$ & $\begin{array}{l}\text { An individual voter's degree } \\
\text { of political event related } \\
\text { emotions }\end{array}$ & $\begin{array}{l}\text { An individual voter's degree } \\
\text { of actual devotion of energy, } \\
\text { effort and time to a political } \\
\text { event }\end{array}$ \\
\hline
\end{tabular}

This working definition and identified gap in the literature has helped to develop two research questions, which will govern the research design of this study. The research questions for this study are as follows:

1. How engaged were young people with the EU Referendum?

2. Can multi-dimensional engagement data be used to profile and segment young voters?

The following section will focus on the research philosophy and approach, insight into participant selection and questionnaire and conclude with reference to the analytical process.

\section{Research Design}

\section{Research Approach}

In this study, the engagement object was the 2016 UK-EU referendum - a one-off political voting event. The empirical data collected focused on the emotions, thoughts, and behaviours of each participant in relation to the vote. The aim of the research was to provide an explanatory account of the inter-relation between the engagement dimensions for young voters. Further, as this study was designed to investigate engagement of young people with the EU Referendum and ascertain whether engagement data could be used to profile and segment young voters, a concurrent mixed-method research approach was adopted. Our approach initially focused on inductive reasoning before combining datasets to explain voter engagement.

\section{Research Methods}

Our research approach was informed by the idea that the voter engagement construct is dynamic (it changes throughout time) and is multi-dimensional (Barrett and Brunton-Smith 2014; Dermody et al. 2010; Lilleker and Koc-Michalska 2017; Thananithichot 2012). The approach was thus designed to capture longitudinal data where possible and combine data collection methods that relate to each specific engagment dimension. Two key research methods were utilised as part of the study: questionnaires (before and after the referendum) and a social network analysis (combining a network analysis of participants' Twitter account relations and the content of their respective discussions online). Questionnaires were designed in order to capture cognitive and emotional responses to the EU referendum immediately before 
and after the vote took place ( 1 week before and 3 days after respectively). Both questionnaires combined a mixture of open and closed questions to probe for reactions to specific topics (Banyard and Grayson 2017), but also to give the participants scope to express their reasons for voting (or not) and their emotional reactions to the voting process. The social network analysis was designed to examine behavioural engagement beyond merely voting, this included of two parts 1) to observe the behavioural relations between young people and political actors online i.e. do people actually interact with EU referendum campaigns, politicians or parties; and 2) To examine the content of young peoples' dialogue online for the presence of behavioural engagement i.e. do people actually talk about political issues online either informally in conversation or formally through dialogue with political actors. The overall structure of the method can be seen below in Figure 1.

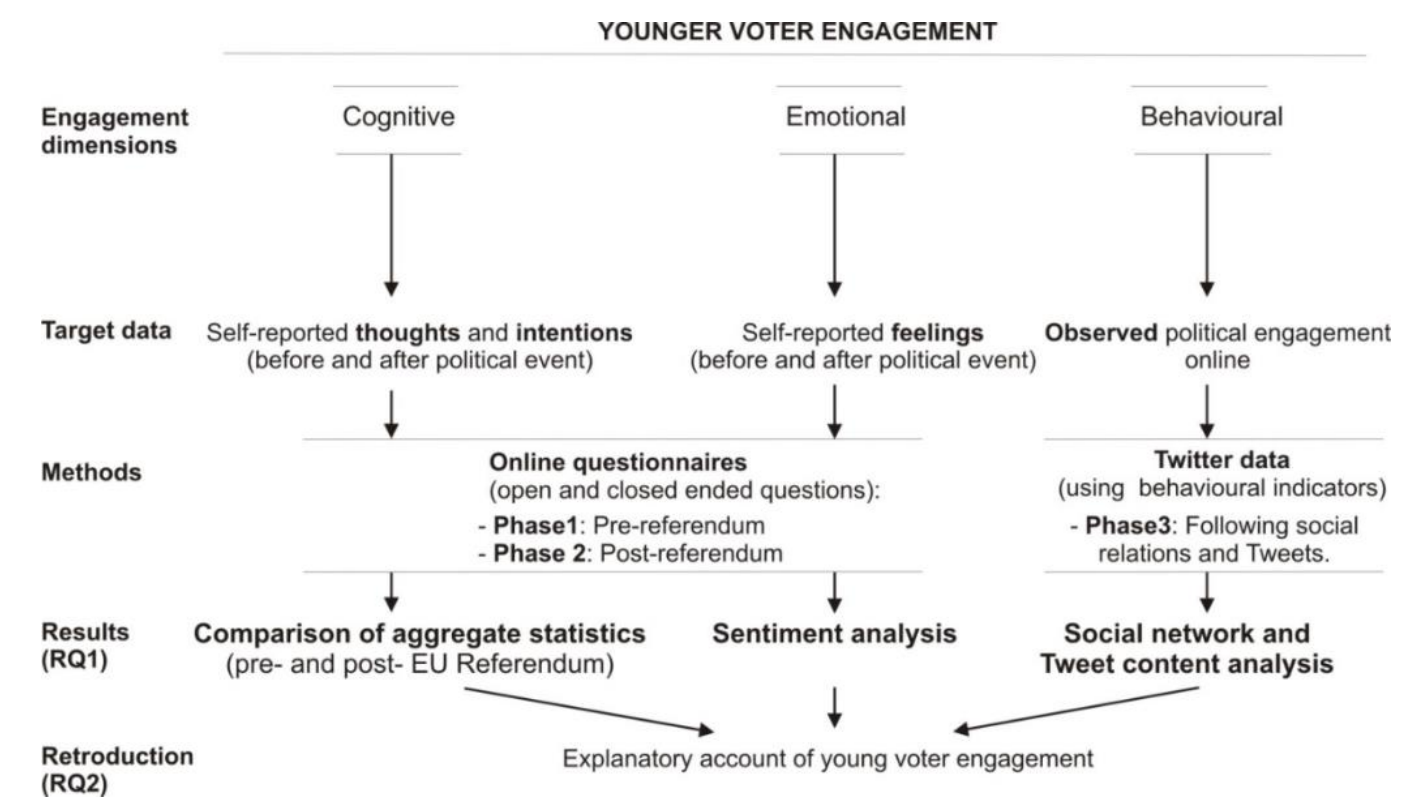

Figure 1: Research Design Overview

Integrating mixed-method data can result in a wide range of threats to validity and legitimacy of study findings (Johnson 2006). However, the use of a mixed-method approach can strengthen the investigative process by capturing additional insight into the phenomena (Creswell 2014; Fetters et al. 2013). Thus the use of social media (e.g. Twitter) was used to complement the online questionnaire [open and closed questions prior and post referendum]. More specifically, the use of Twitter to get insights from consumers is becoming increasingly common in the current research environment (Nunan and Yenicioglu 2013). The process of gaining permission for this form of data collection can be an issue for researchers (Nunan and Yenicioglu 2013) because people can react with hostility when they become aware that they are the object of study for researchers (Hudson and Bruckman 2004). This reaction reflects some of the ethical concerns raised by data collection from platforms such as Twitter, and these worries include privacy, informed consent and the difficulty of applying ethical theory to this context (Conway 2014; Kozinets 2002).

\section{Sampling Framework}

Participants were purposefully selected using a non-probability sampling technique (Saunders et al. 2015). Purposive sampling involves selecting respondents based on characteristics of the population and appropriately selected to address the overall research objectives (Alston and 
Bowles 2007; Zikmund 2003). To reiterate young people [18-24 years] are often characterised as alienated, mistrustful and disinterested with politics compared with every other age group, complex in nature yet represent an untapped market to political parties and politicians (Barrett and Brunton-Smith 2014; Charles 2009; Dermody and Hanmer-Lloyd 2004; Dermody et al. 2010; Macnamara et al. 2012). Further, this is supported by explicit calls for further research and new insights on young voter engagement (Boonen et al. 2014; Fieldhouse et al. 2007; Henn et al. 2002; Henn et al. 2005; Wagner et al. 2012). Thus, young voters represented the target sample for this study and the prerequisites for this study were that they should be aged between 18-24, must be a UK resident and must have an active Twitter account and be willing to share data with the research team. Therefore, no additional demographic data such as social, regional and educational background was collected. However, this could have been used to build a profile of the sample and future studies should address this. Participants were given a $£ 10$ Amazon voucher as remuneration for their participation after the final phase of data collection. Sample attrition was relatively high across data collection phases $(>20 \%)$, some of this was due to participants not having an accessible Twitter account from which data could be captured.

The advert was distributed across social media channels and university email lists with encouragement for participants to share details of the research and help to advertise the study The questionnaire required self-selection by participants, however the research advert was nondescript in reference to politics or specific behavioural patterns of social media use. Since its creation in 2006, Twitter has been used extensively to understand behaviour in the fields of marketing and politics (Conway 2017). As Bulearca and Bulearca (2010) point out, Twitter is distinctive from other social media platforms in terms of both characteristics and growth. The essence of events can be transmitted immediately across the network (Jansen et al. 2009), which makes it an attractive context to recruit participants. As we adopted a non-probability sampling technique the socio-economic status of the participants could not be guaranteed, but given the exploratory nature of this study and the focus on the engagement construct itself (rather than the relation between participant background and engagement) it was not a threat to the legitimacy of the method. In addition, it is important to highlight that we make no claims of generalisability of the findings as our research questions aimed to understand how young people engage with a political event. Therefore, the representativeness of the sample should be considered in future quantitative research. This is set out set out in point three of directions for future research section.

\section{Analytical Process}

\section{Questionnaire Design and Sentiment Analysis}

The questionnaire was completed by participants online and in their own time using the web service named Qualtrics. Responses to the first stage were required to be completed before the day of the vote (EU referendum polling day - June $23^{\text {rd }} 2016$ ), whereas the responses to the second questionnaire were completed over a period of 3 days after the results were released. A total of 101 participants took part in the first questionnaire, and 78 of which were involved in the further second questionnaire.

During the second phase of the questionnaire participants were asked the question 'how would you describe the result of the EU referendum' and given the opportunity to provide an answer in their own words. The results were then computationally analysed for emotional valence using an academic sentiment analysis tool named Sentistrength (Thelwall et al. 2010; Thelwall and Buckley 2013). This tool gives each word in the response a positive and negative score (depending on the expressed emotional strength) which are then combined to give an overall 
valence. This score can be plotted on a continuum from -4 to +4 to give a sense of the overall quantitative strength of the voters' emotional engagement. The scale begins at -1 (not negative) to -5 (extremely negative) and 1 (not positive) to 5 (extremely positive) - zero is not used until the numbers are combined. The reason for the dual score is that recent research suggests that people can and do experience mixed valences of emotion which often appear to be in conflict (Berrios et al. 2015), this is of especial interest in the case of political engagement to help reveal cases where people may feel emotionally conflicted about participation.

\section{Social Network Relations and Tweet Content Analysis}

A longitudinal social network analysis was conducted by computationally scraping data from the social network service Twitter. The dataset included social relations of participants and their personal tweets. The aim was to reveal behavioural aspects of voter engagement external to the self-reported data in the questionnaires and avoid attitude-behaviour gaps which may occur when speaking to participants. This was therefore an attempt to present an etic account of voter engagement through observation.

Accounts were mined using Twitter's API (application programming interface) and were exported into Microsoft Excel for subsequent analysis. Account details captured included tweet history (up to the previous 3000 tweets) and account following (who the users themselves follow). All three of these datasets were generated in order to examine evidence of political discussion online, either indirectly with followers, or through direct conversation with formal political accounts (official MP, MEP, political parties, or referendum campaign accounts). The corpus of formal political accounts was created by the research team by collating lists of official EU referendum campaigns, members of parliament, members of European members of parliament, and major political parties in the UK. The process of compiling this list was done by cross-checking a list of MPs, MEPs and parties in office for official Twitter accounts. This process was aided by open access watchdog websites that monitor tweeting of political actors online (e.g. www.mpsontwitter.co.uk 2016).

The number of respondent Twitter accounts successfully mined was 71. Lookup tables were generated in Microsoft Excel for analysing the prevalence of informal political discussions, direct dialogue and ongoing engagement (following relations). The lookup tables of official formal political Twitter accounts included: 73 MEPs with active Twitter accounts (4 without); 554 MPs with active Twitter accounts (88 MPs without); and 12 party political and official EU referendum campaign Twitter accounts. The number of tweets mined across all of the accounts was 156,650 with a mean average number of 2206.3 Tweets per respondent. The text of the tweets were examined for mentions of political accounts either indirectly (discussed generally in public) and direct mentions (using the @ symbol which denotes a direct notification of the user in question). Where tweets were found containing mentions the research team manually examined the tweets to validate the computational analysis.

A limitation of the online behavioural data is that it was only gathered through Twitter and thus represents only one specific form of social media with distinct functional characteristics. The rationale for this is that Twitter is the "leading platform among microblogging forms of social media that provides a way of broadcasting brief posts" (Fischer and Reuber 2011:3). Further, Twitter enables users to 'share' personal thoughts, attitudes and opinions and follow individuals, organisations and campaigns (Bulearca and Bulearca 2010; Fischer and Reuber 2011). The vast majority of Twitter data is publicly accessible for data scraping in contrast to other platforms such as Facebook, Instagram and Snapchat (Nulty et al. 2016). 


\section{Results and Discussion}

This section sets out the results from the study and links the findings back to the existing literature. We first examine political engagement for young voters around the EU referendum and discuss our findings in light of the marketing engagement literature to answer the first research question. Next, we analyse the extent young voters fit into qualitatively distinct engagement segments, and provide an account of prototypical engagement characteristics, thus answering the second research question.

\section{Young voters political engagement}

Question 1 of this study investigated how young people are politically engaged pre and post the 2016 EU referendum. This section is divided into three parts, specifically: (1) A comparison of aggregate statistics pre and post-referendum, (2) a sentiment analysis of respondent comments and (3) a social network analysis of political broadcasting, subscription and dialogue initiated by participants.

\section{Comparison of aggregate statistics for pre-and post EU Referendum.}

The 'cognitive' results displayed in table 3 demonstrate how varied voter intentionality was and how some participants changed when comparing their intentions pre- and postReferendum. One of the most striking figures is that, $84 \%$ of our young voters aged 18-24 years were strongly inclined to vote before the EU Referendum and their willingness to vote in a second Referendum increased up to $96 \%$ after knowing the Referendum results. This tendency is consistent with participants' opinion. In fact, the majority of young voters (79\%) believed the UK should remain a member of the European Union and in the case of a second Referendum, $82 \%$ said they would choose remain. In contrast with the strong voting intention for a Second Referendum, only $86 \%$ of participants would be certain to vote in a future General Election as indicated in the second half of Table 3. This suggests engagement with future referendums [intermittent elections] seems stronger than periodic elections [General election]. It is beyond the scope of this research to investigate the rationale for this discrepancy. Nevertheless, this is consistent with the notion that young people are less likely to vote and less likely to be involved in conventional political activities. Perhaps referendums [intermittent elections] could be seen as non-conventional in the sense the unique nature of a referendum, which has a different objective from General Elections is the reason more young voters would vote in a second EU Referendum (Barrett and Brunton-Smith 2014; Macnamara et al. 2012). This suggests that young voting habits are 'malleable' and the prospect of shaping or influencing the electoral biographies of young voters as a means to strengthen engagement for future elections-voting will appeal to political parties and campaign groups (Barrett and Brunton-Smith 2014; Gorecki 2013).

When comparing political preferences pre- and post- Referendum for an upcoming General Election, participants were fairly consistent, with two exceptions. First, pre-referendum, in the 2015 UK General Election, 33\% of participants voted Conservative and 23\% of participants voted Labour, however more participants preferred Labour [33\%] than Conservative [31\%] in a hypothetical future General Election. This preference changed again post-referendum where more participants indicated support for the Conservatives [44\%] compared with Labour [28\%]. Whilst the change in opinion polls between elections is not surprising, the trend from our study 
seems consistent with national General Election polling at the time (www.ukpollingreport.co.uk). Since this study was conducted, the UK political landscape has changed again as a result of the 2017 snap-General Election. Second, the percentage of participants who would not vote in upcoming General Elections dropped from $16 \%$ [prereferendum] to 5\% [post-referendum]. This is interesting as more young voters would vote in future UK General Elections after taking part in the EU Referendum, which suggests actual engagement and participation can impact on future engagement and possibly habitual voting (Barrett and Brunton-Smith 2014; Gorecki 2013; Nickerson 2006).

Table 3: Participants' Voting Intention for EU Referendum and General Election

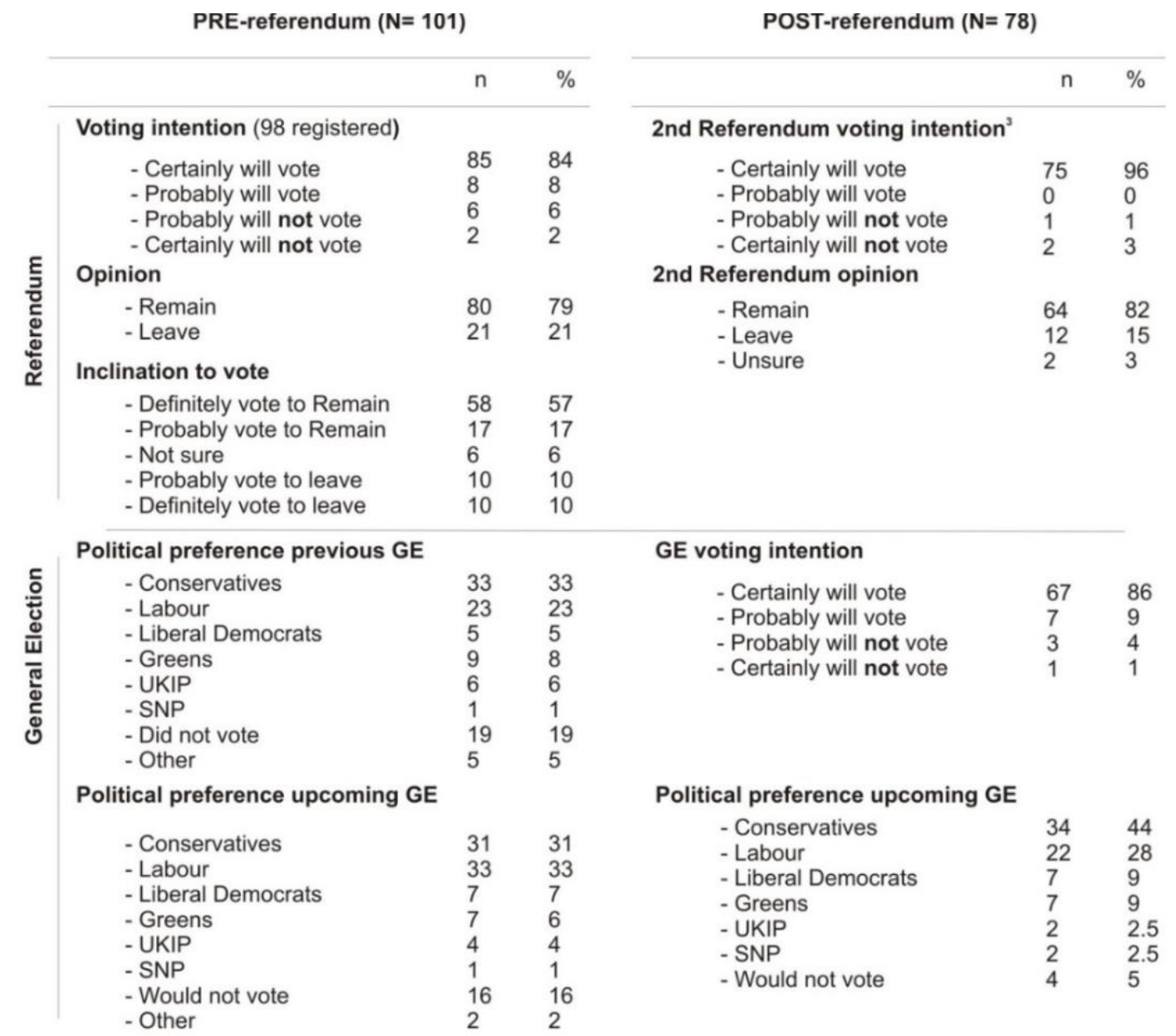

${ }^{3}$ For the POST-referendum the voting questions were based on the motivation to vote in a second referendum.

When asked about the key issues that influence voting choice before and after the EU referendum the participants' answers varied. As Figure 2 indicates, there are some notable differences in the key issues identified. Prior to the referendum, 56\% of participants identified the 'economy' as the key factor for voting. However, following the referendum, $67 \%$ of participants based their decision on the 'economy' regardless of whether they voted remain or leave. The second key factor for voting was the 'free movement of people' $-14 \%$ prior and $10 \%$ post. Therefore, the economy was a major deciding factor in the decision making process when participants cast their vote. The findings suggest that most young voter in our sample were knowledgeable about political issues (Dermody et al. 2010) and evidenced some thought elaboration and processing in relation to the event (De Vreese 2005; Pinkleton and Austin 2002). 


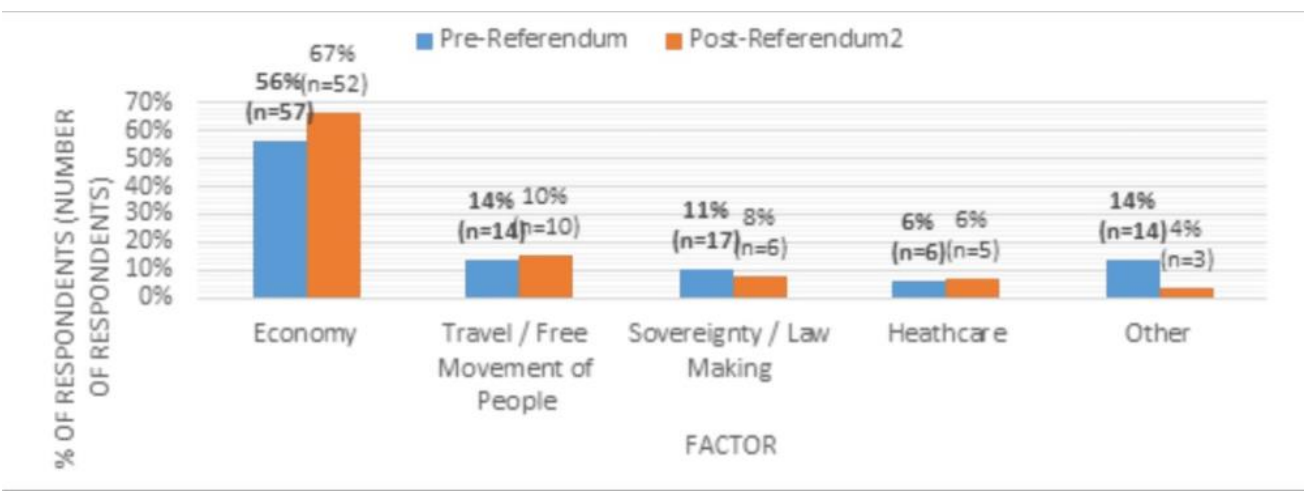

Figure 2: Comparison of key issues for young voters before and after EU Referendum

Figures $3 a$ and $3 b$ present a comparative account of participants' perceptions to key issues before and after the referendum took place. A range of topics that featured centrally in official EU referendum marketing campaigns were put to the participants for their personal view on whether the UK would be better or worse off in the respective area if the UK voted to leave the EU. Generally, participants perceived that the UK would be worse off if the UK voted to leave the EU: economic impact (pre $=77 \%$, post $=73 \%)$, the impact on jobs $($ pre $=68 \%$, post $=66 \%$ ), the UK's global influence (pre $=61 \%$, post $=58 \%$ ) and for the participants personally (pre= $57 \%$, post $=62 \%$ ). By contrast, participants thought the UK would be better off in terms of the price of goods and services (pre $=76 \%$, post $=81 \%$ ). The perceived risk from terrorism remained similar ( $\mathrm{pre}=56 \%$, Post $=54 \%$ ). Overall, the results remained largely consistent in most categories across both questionnaire phases, pre- and post-referendum.

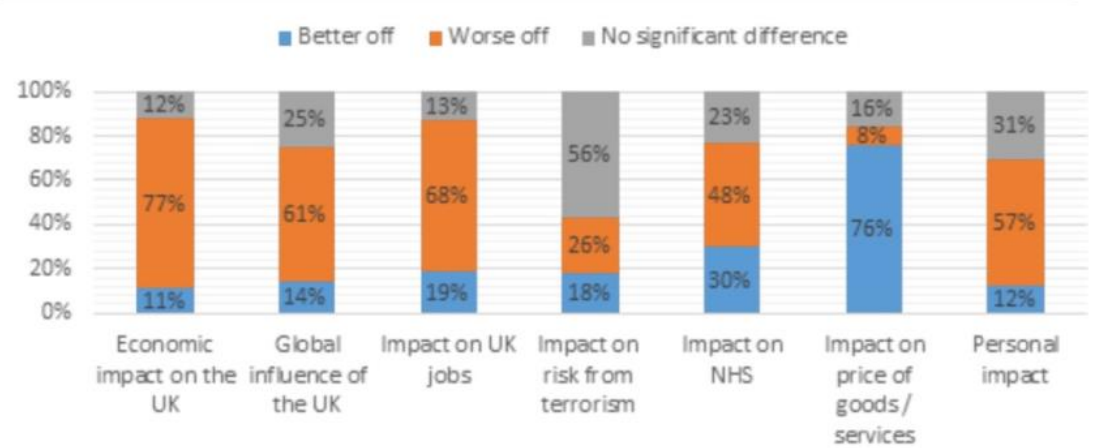

Figure 3a: Perceptions of kev issues considered bv voung voters PRE-Referendum

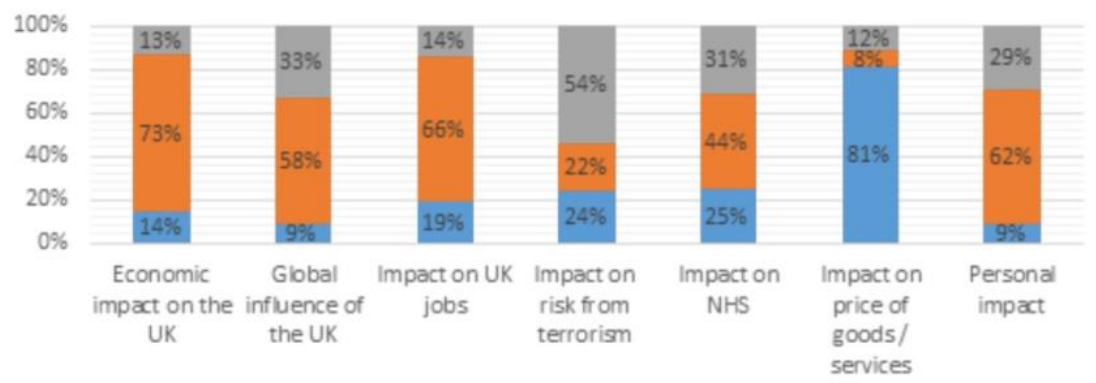

Figure 3b: Perceptions of key issues considered by young voters POST-Referendum

Figure 3: Comparison of young voter perceptions of key issues pre- and post EU Referendum 


\section{Sentiment analysis}

Following the referendum, participants were asked to provide one sentence to describe the result (see Table 4). The majority of young 'leave' voters $(\mathrm{n}=14)$ revealed a positive emotional valence, optimistic responses such as "sensational", "hopeful for the prosperity of the UK economy" and "I'm excited by what the future holds for the UK". On the contrary, the majority of young 'remain' voters $(\mathrm{n}=70)$ expressed negative pessimistic views such as "people of the UK fucked up", "disappointing and sad. People let lies and scaremongering influence them" and " $a$ victory for isolation, xenophobia and the irrationality of the mob".

Remain voters generally provided a more negative valence swing than leave voters when responding to the question 'how would you describe the result of the EU referendum'. For remain voters the mean average valence when scores were combined was -1.26 (SD 1.54). Whereas for leave voters the mean average valence when scores were combined was +0.43 (SD 1.50). It is hardly surprising that remain voters were disappointed with the result and leave voters were pleased with the outcome of the referendum. However, there was also an element of uncertainty with some 'leave' voters. Two participants regretted their leave vote when asked in the second questionnaire and indicated that they would have voted remain if given another opportunity. Many of the remain voters also questioned the legitimacy of the vote itself despite participating. This supports the idea that young voters can be critical and cynical of politics yet engage with the political process (Dermody et al. 2010; Macnamara et al. 2012; Nickerson 2006).

In addition, a broader theme emerged in which eight 'remain' voters were frustrated or angry with the outcome but directed their frustration primarily at older generations. $57 \%$ of voters aged 55-64 and $60 \%$ of voters aged $65+$ voted to 'leave' the European Union (Clarke et al. 2017). The negative emotional valence expressed by participants towards older people is exemplified by comments such as "gutted, such a poor decision made by the majority of elder population which the younger generation clearly didn't want" and "disappointing, especially considering the results of age groups voting i.e. the older generation majority wanted to leave and deciding the future of the younger generation that wanted to stay". Therefore, many young remain voters attributed the result of the EU referendum to the actions of the older generation. The consequence is a tense generational divide. This reinforces the complexity emotivecognitive characteristics of young voter engagement and participation. 
Table 4: Sentiment analysis of participants' comments including combined valence scores

\begin{tabular}{|c|c|c|c|c|}
\hline & $\mathbf{n}$ & mean & SD & In one sentence, how would you describe the result of the EU Referendum? \\
\hline LEAVE voters & 14 & 0.43 & 1.50 & $\begin{array}{l}\text { "Fantastic" (Peter, did not vote'). } \\
\text { "A heaving roar from the disillusioned, which has started the metropolitan political } \\
\text { class into finally listening to them" (Jack, Conservatives). } \\
\text { "Hopeful for the prosperity of the UK Economy" (Louise, Conservatives). } \\
\text { "Uncertain, challenging and slightly devastating, but change is good and can } \\
\text { work this out to benefit us if everyone comes together" (Shelley, Conservatives). } \\
\text { "A positive opportunity for Great Britain" (Anne, UKIP). } \\
\text { "Sensational" (Julie, did not vote). } \\
\text { "A success"(Sarah, Conservatives). } \\
\text { "I am excited by what the future holds for the UK" (Nick, Conservatives). } \\
\text { "The result was fair and I feel it was the right result (Olivia, UKIP). }\end{array}$ \\
\hline REMAIN voters & 62 & -1.26 & 1.54 & $\begin{array}{l}\text { "A complete shit show" (Lisa, Liberal Democrats). } \\
\text { "The people of the U.K. fucked up" (Rose, Labour). } \\
\text { "A victory of misinformation and fear mongering" (Matt, did not vote) } \\
\text { "A victory for isolationism, xenophobia, and the irrationality of the mob" } \\
\text { (John, Labour). } \\
\text { "Disappointing and sad. People let lies and scaremongering influence them" } \\
\text { (Emily, Greens). } \\
\text { "Shocking - those who voted leave believed a bunch of idiots who lied to them. } \\
\text { Half of them probably voted because of immigration but were too stupid to realise } \\
\text { that it probably wouldn't make much difference" (Melanie, Conservatives). } \\
\text { "Irritating, but democratically reached, although the handling of the result and } \\
\text { planning for the future has been a clusterfuck" (Teresa, Labour). }\end{array}$ \\
\hline $\begin{array}{l}\text { REMAIN voters: } \\
\text { frustration over } \\
\text { generational } \\
\text { divide }\end{array}$ & 8 & -0.63 & 1.85 & $\begin{array}{l}\text { "I would describe the result as disappointing and detrimental for my generation } \\
\text { the vote was a result of a lot of propaganda and ignorance and unfortunately will } \\
\text { impact my generation the most" (Caroline, Conservatives). } \\
\text { "Disappointing for young people, who mostly voted to remain. The general feeling } \\
\text { amongst my peers is that the older generation made the decision to leave which will } \\
\text { have more of an impact on young people, and this doesn't seem fair. (Thomas, Labour). } \\
\text { "Everyone voted for the good of themselves, the elderly for out and the young for } \\
\text { remain. With more elderly voters resulted in leaving the EU" (Jane, Labour). } \\
\text { "Absolutely gutting: I feel the outcome is unfairly voted on by an older generation } \\
\text { that won't see the true effect of the consequences; I am disappointed many young } \\
\text { people didn't vote at all and I am most upset that some have used Brexit as a platform } \\
\text { to validate racist views :(" (Helen, Conservatives). } \\
\text { "Gutted, such a poor decision made by the majority of elder population which the } \\
\text { younger generation clearly didn't want."(Eve, Labour). } \\
\text { "Dissappinting, especially considering the results of age groups voting ie the older } \\
\text { generation majority wanted to leave and deciding the future of the younger } \\
\text { geneneration that wanted to stay" (Ian, Greens). } \\
\text { "As a student, heartbreaking" (Malcolm, Greens). } \\
\text { "Not a good result for the youth of the country" (Abraham, did not vote). }\end{array}$ \\
\hline
\end{tabular}

' Previous vote in the general election 2015

${ }^{2}$ Emphasis added 
Social Network Analysis: Respondent Broadcasting, Subscription and Dialogue

Respondent Broadcasting. The results show that young voters expressed opinions on a wide variety of political issues online. Table 5 reveals that participants discussed political parties $(61.97 \%)$ and political topics $(83.09 \%)$ generally, but also were very active in discussing the EU referendum specifically (45.07\%) and its associated marketing campaigns. 'Labour' and 'UKIP' were the most discussed parties followed by the 'Conservatives' and the 'Scottish National Party'. In addition, key political topics such as 'jobs', the 'economy', 'Brexit', 'NHS' and the infamous ' 350 million' that would be given to the NHS if the UK voted to leave the EU were also discussed by participants. This suggests young voters were actively concerned with politics in the lead up to the referendum and had also well-elaborated thoughts in relation to the event. This supports the idea that digital platforms can strengthen engagement and develop political interest (Koc-Michalska and Lilleker 2017; Lilleker and Koc-Michalska 2017; Macnamara et al. 2012; Mann and Mayhew 2015). 
Table 5: Social Network Analysis

\begin{tabular}{|c|c|c|c|c|c|c|}
\hline Respondent behaviour & & $\begin{array}{l}\text { Total } \\
\text { count }\end{array}$ & \multirow[t]{2}{*}{ Mean Avg } & \multirow[t]{2}{*}{ SD $u$} & $\begin{array}{l}\text { Unique } \\
\text { user count }\end{array}$ & \multirow[t]{2}{*}{$\begin{array}{l}\text { Unique as } \\
\% \text { of total }\end{array}$} \\
\hline \multirow{34}{*}{$\begin{array}{l}\text { BROADCASTING } \\
\text { Do respondents discuss } \\
\text { political topics in public } \\
\text { online? }\end{array}$} & \multicolumn{3}{|l|}{ Political party keywords: } & & & \\
\hline & - Labour & 550 & 7.75 & & & \\
\hline & - Conservatives/tories & 194 & 2.75 & & & \\
\hline & - Greens/Green party & 26 & 0.37 & & & \\
\hline & - UKIP & 330 & 4.65 & & & \\
\hline & - Liberal democrats/Lib democrats & ts 100 & 1.24 & & & \\
\hline & - Plaid Cymru & 3 & 0.04 & & & \\
\hline & - Scottish National Party/SNP & 181 & 2.55 & & & \\
\hline & - DUP & 10 & 0.14 & & & \\
\hline & - Sinn Fein & 1 & 0.01 & & & \\
\hline & TOTAL PARTY & 1395 & 17.22 & 52.15 & 44 & 61.97 \\
\hline & \multicolumn{6}{|l|}{ Political topics keywords: } \\
\hline & - Politics & 595 & 8.38 & & & \\
\hline & - Employment & 24 & 0.34 & & & \\
\hline & - Jobs & 112 & 1.58 & & & \\
\hline & - Economy & 88 & 1.24 & & & \\
\hline & - GDP & 10 & 0.14 & & & \\
\hline & - Immigration & 69 & 0.97 & & & \\
\hline & - Free movement & 5 & 0.07 & & & \\
\hline & - NHS & 96 & 1.35 & & & \\
\hline & - Healthcare & 7 & 0.10 & & & \\
\hline & - Terrorism & 64 & 0.90 & & & \\
\hline & - Sovereignty & 11 & 0.15 & & & \\
\hline & TOTAL TOPIC & 1081 & 13.30 & 32.37 & 59 & 83.09 \\
\hline & \multicolumn{6}{|l|}{ Referendum keywords: } \\
\hline & - EU Referendum & 54 & 0.75 & & & \\
\hline & - Strongerin / Stronger in & 68 & 0.95 & & & \\
\hline & - Voteleave / Vote leave & 77 & 1.08 & & & \\
\hline & - EU & 266 & 3.75 & & & \\
\hline & - Brexit & 294 & 4.14 & & & \\
\hline & - 350 million / 350m & 15 & 0.21 & & & \\
\hline & - take back control & 4 & 0.06 & & & \\
\hline & - better off out/ betteroffout & 3 & 0.04 & & & \\
\hline & TOTAL REFERENDUM & 781 & 9.64 & 37.16 & 32 & 45.07 \\
\hline \multirow{3}{*}{$\begin{array}{l}\text { SUBSCRIPTION } \\
\text { Do respondents follow } \\
\text { politicians and/or interest } \\
\text { groups on Twitter? } \\
\text { (accounts followed) }\end{array}$} & MPs & 364 & 5.13 & 21.92 & 20 & 28.17 \\
\hline & MEPs & 12 & 0.17 & 0.87 & 4 & 5.63 \\
\hline & Party and Official EU referendum & 16 & 0.23 & 0.76 & 9 & 12.68 \\
\hline \multirow{3}{*}{$\begin{array}{l}\text { DIALOGUE } \\
\text { Do respondents } \\
\text { communicate directly with } \\
\text { politiciansand/or interest } \\
\text { groups using@ signs on } \\
\text { Twitter? }\end{array}$} & MPs & 864 & 10.66 & 39.30 & 26 & 36.62 \\
\hline & MEPs & 72 & 0.88 & 4.22 & 12 & 16.90 \\
\hline & Party and Official EU referendum & 157 & 1.93 & 6.93 & 19 & 26.76 \\
\hline
\end{tabular}

Twitter Subscription. It was found that each respondent pursued and subscribed to information about other people and organisations on the social networking service Twitter. Following the analysis of social network relations and tweet content, it was found that 20,902 accounts (nodes) with 24,422 relations (edges), highlighted a large variety of overlapping relations between participants. This is to be expected for Twitter - which is typically used to connect with existing relations such as friends, family, and colleagues alongside more abstract relations such as celebrities, interest groups, activists, politicians and parties. The mean average follows 
for participants $(343.97)$ and standard deviation $(\mathrm{SD}=270.50)$ demonstrate that despite large variance within the sample, it nonetheless offers a wealth of insights into the interests and conscious choices of young people online.

The results illustrate that young people were not just discussing political issues or topics but were actively following political stakeholders such as elected representatives and political organisations. This is consistent with the notion that young people are knowledgeable of political issues and actively discuss politics (Dermody et al. 2010; De Vreese 2005; Pinkleton and Austin 2002). 28.17\% of participants actively followed at least one MP, $5.63 \%$ followed at least one MEP, and $12.68 \%$ followed at least one party or official EU referendum account. Social media is now a key tool in fostering relationships between young voters and political parties (Dermody et al. 2010; Dermody and Hanmer-Lloyd 2004), and increases the likelihood of young voters being exposed to political marketing campaigns. It is clear that a large portion of respondents in this sample use Twitter as a source of political news to stay informed.

Dialogue. The findings reveal that there is formal dialogue between young voters and political stakeholders such as politicians and political interest groups. For example, $36.62 \%$ of participants communicated directly with MPs by using the @ sign on Twitter, 16.9\% communicated directly with MEPs, and $26.76 \%$ communicated directly with party and official EU referendum accounts. Many participants communicated directly with Members of Parliament such as 'remain' supporters 'Tim Farron' [Liberal Democrat], 'Karl Turner' [Labour] and 'Anna Soubry' [Conservative]. However, fewer participants communicated directly with 'leave' supporting Members of Parliament nevertheless, 'Daniel Hannan' [Conservative] and 'Nigel Farage' [UKIP] were two exceptions. The results highlight the huge variance of behavioural engagement for young people in the context of political discussion and self-selected political networks. This reaffirms the idea that young people can, and indeed do, form a sense of personal involvement with the political process. The results also demonstrate that young people exhibit a range of non-conventional behaviours which illustrate deep political engagement (Barrett and Brunton-Smith 2014; Dermody et al. 2010; De Vreese 2005; Pinkleton and Austin 2002).

\section{Explanatory account of young voters' political engagement}

The second research question aimed to understand whether multi-dimensional engagement data can be used to profile and segment young voters. The traditional marketing activities of audience segmentation, targeting and positioning rely on the initial possibility of profiling individuals and classifying them according to distinct segments. Audience segmentation provides the basis for a greater degree of tailoring and personalisation in marketing communications. Young voters can be classified according to whether or not they are engaged behaviourally, cognitively and emotionally. But the voter engagement construct is a compound from three inter-related dimensions and neither of these dimensions are necessary or sufficient to indicate engagement generally. With this in mind, we this paper puts forward 'Overlapping Engagement Characteristics and Prototypical Engagement Persona Typology' (figure 4) and outlined below. Each Prototypical Engagement Persona (PEP) is defined through the presence/absence of qualitatively distinct engagement characteristics (behavioural, cognitive, and emotional) which, when viewed in configuration, give a gestalt picture of an individual's momentary state of engagement. 


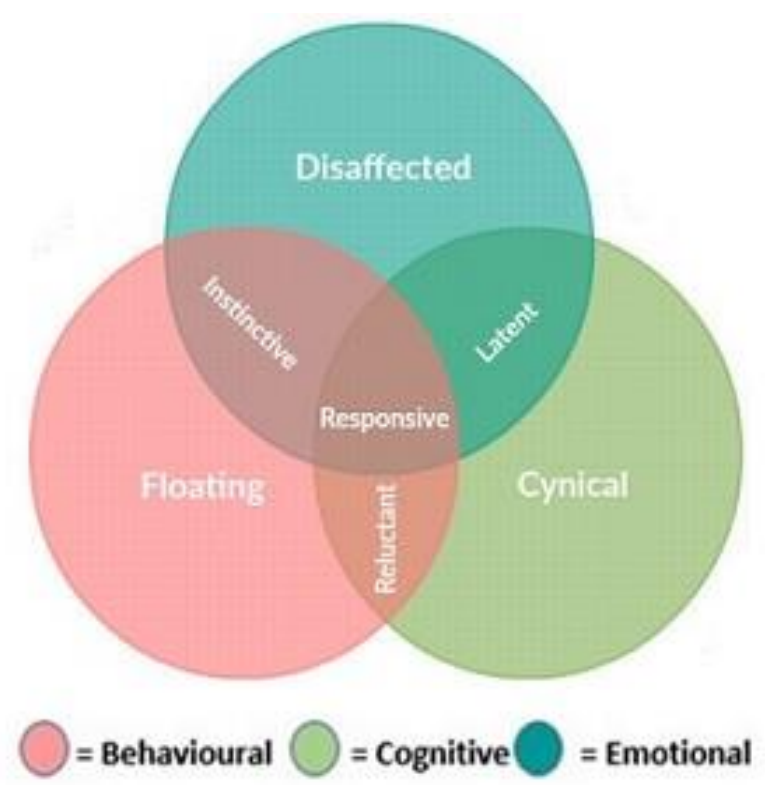

Figure 4: Overlapping Engagement Characteristics and Prototypical Engagement Persona Typology

It should be noted that engagement is processual so any given individual will inevitably pass through multiple PEPs within their lifetime, but the identification of these momentary snapshots of engagement provide an insight to help understand how young peoples' engagement with politics transforms throughout time. In the discussion that follows each PEP of the proposed typology is discussed in turn and this is followed by a discussion of further research avenues that could utilise PEPs to inform political marketing campaigns.

\section{Responsive (Cognitively, Emotionally and Behaviourally Engaged)}

A responsive young person is defined as being fully engaged cognitively, emotionally, and behaviourally with the political event. They have responded across all engagement dimensions to the marketing of the event. These people are aware of the political event, have registered to vote, participate in the voting process, have clearly-elaborated thoughts on the event (knowing their representative MPs, MEPs and parties) and have an emotional response to the process. They possess an intentional state of voting in the future, but also demonstrate behavioural engagement beyond the voting booth in the present - they discuss political issues, subscribe to news about political actors, and even engage directly with political actors in order to persuade others according to their own respective political agenda.

\section{Latent (Cognitively and emotionally engaged, but lacking behavioural engagement)}

A latent young person is defined as being cognitively and emotionally engaged, but not behaviourally engaged. These people have responded to the marketing of the political event, but fail to actualise their engagement through participation in the voting process or beyond the voting booth. These people are typically aware of the event, have clearly-elaborated thoughts on the event and have an emotional response to the associated marketing campaigns. They may possess a positive intentional state for future political participation, but this fails to translate into action in the present moment. Indeed, these participants are most likely to be the young people who say they 'forgot' to register to vote when asked for the reason for nonparticipation. 


\section{Cynical (Cognitively engaged, but lacking emotional and behavioural engagement)}

A cynical young person is defined as someone cognitively engaged who fails to participate in behavioural engagement and lacks a discernible emotional response to any of the possible political outcomes. These people are aware of the event and have views about the consequences of the event, but fail to act in response to it. It is important to stress that the cynicism used to describe this category is not necessarily restricted to a cynicism of the event itself, as it may relate to a personal assessment of the young person's own moral status i.e. they may ask the question 'is it right that I am participating in this event?' and subsequently lack the moral impetus or even confidence to participate.

\section{Disaffected (Emotionally engaged but cognitively and behaviourally disengaged)}

A disaffected voter is defined as a person engaged emotionally, but not cognitively or behaviourally. Although the person is aware of the political event and may even feel strongly that the result is positive or negative, this is not evidenced in the reasons they give or observed through behavioural participation. The disaffected voter represents a challenge for policy makers and anyone trying to encourage widespread democratic participation.

\section{Instinctive (Behaviourally and emotionally engaged, but lacking cognitive engagement)}

An instinctive voter is defined as being behaviourally and emotionally engaged but lacking a clear and reasoned position. The instinctive voter may be conflicted about participation, but similarly feel that the event is important even if they have a limited ability to conceptualise or articulate a reason for participation beyond gut feeling or affect. The anticipation of negative consequences followed by an expression of confusion and disappointment after voting for a successful outcome illustrates an inability to clearly articulate reasons in an ordered manner. Although participation is seen as important to this category of young voters they may actually be the most unresponsive to subsequent political marketing, especially if marketers are unable to identify the political priorities of voters because their primary goal is political union rather than coping with the presence of dissent in their social lives.

\section{Reluctant (Behaviourally and cognitively engaged, but lacking emotional engagement)}

The reluctant voter is defined as being behaviourally and cognitively engaged, but lacking an emotional commitment to any outcome in the political event. The reluctant voter is characterised by a refusal to express a fully emotional engagement with the process because they see the process as misinformed, illegitimate, or misleading from all directions (not merely because of partisan bias). Nevertheless they participate in the process, often because they see democratic participation as important regardless of their perspective of the event. The reluctant voter is aware of and knowledgeable of the political event (in this case also knowing local MP, MEPs and formal campaigns), registers to vote in the event, actually votes, and discuss informal topics through broadcasting, subscription and dialogue. However, there is a consistent reluctance to fully accept the political event and consequently they suffer emotional dissonance during participation. Whether emotional disengagement can act as a mechanism to cause behavioural and cognitive disengagement remains a potentially insightful avenue for future research with profound consequences, especially as it relates to protest votes and 'spoiling the ballot'.

\section{Floating (Behaviourally engaged but not cognitively or emotionally engaged)}

The floating engagement persona is defined as a young person that exhibits some behavioural engagement, but lacks cognitive and emotional engagement. The floating voter is non- 
committal, expressing neither elaborated reasons nor emotional valence in relation to vote outcomes, but nonetheless exhibits observable evidence of behavioural engagement. The behavioural engagement in this persona could be present in the form of voting without expressing cognitive or emotional engagement or more likely, the behavioural engagement is seen in partial glimpses outside of the voting booth, such as registering to vote or discussing political issues in relation to the event.

\section{Conclusion and directions for future research}

At the heart of this paper is the proposition that young voter engagement is multifaceted and complex. Our study reveals young people were engaged with political discussion, actively follow political accounts online, and directly communicate with political representatives and organisations. Further, our study suggests current engagement remains connected with future engagement and highlights the challenges of sustaining long-term political interest due to the 'malleable' nature of young voters' electoral biographies (Barrett and Brunton-Smith 2014; Gorecki 2013; Nickerson 2006). This paper concurs with the notion that young voters can be interested in politics yet remain critical and distrusting of political institutions, the establishment and the electoral process. Our findings support the idea that young voters who are interested and knowledgeable of political issues can offset negative emotional valence that would otherwise prevent behavioural engagement (Dermody et al. 2010; De Vreese 2005; Pinkleton and Austin 2002). Nevertheless, this could be context specific as the study was framed around the 2016 EU Referendum, which raises questions about future research and applicability beyond this case.

We suggest that young voter engagement is not only context specific, but also concept specific, in terms of how voters inter-subjectively conceptualise the event itself. Our findings contribute to the evaluation of voter engagement as a dynamic process that changes through time as voters change their level-degree of engagement from election to election. Engagement is a multidimensional construct with overlapping characteristics, with no single characteristic considered superior. One of the main contributions of this paper is to use the engagement construct for the practical purpose of classification, which can subsequently be used for audience segmentation and targeting. The classification typology that we name Prototypical Engagement Persona (PEPs) is polythetic, but nonetheless helps to conceptualise the actual extent and variance of the three dimensions of engagement. The classification schema thus serves as a practical tool to help understand the complexity of young voter engagement and inform marketing planning. Below we list a series of research objectives which future research should attempt to focus on in order to develop the legitimacy and validity of the PEP typology:

1. Future research could adopt the PEP typology as grounding for a qualitative in-depth exploratory study to understand the apathy of young voters and their engagement with the electoral process following the 2016 UK-EU Referendum. More specifically, the application of the PEP typology will support the examination the engagementdisengagement of young voters following the 2017 UK General Election and assess future voting intention and re-engagement of young citizens 18-24 years. This in turn could assess the applicability of the PEP typology as a mechanism to understand young voter engagement, disengagement and re-engagement which remains topical and highly relevant area of future research.

2. Alternatively, future research could deploy the PEP typology as a quantitative scale to measure repeated citizen engagement dimensions across large samples, jurisdictions or different demographic groups. Engagement should be understood as a temporal 
phenomenon and is easiest to conceptualise through repetitive political events such as general or local elections. We believe the efficacy of PEP profiling and segmentation, according to the three engagement dimensions, will offer greater efficacy and insight when repeated longitudinally with a sample group.

3. Demographic and psychographic data are routinely employed to segment and target political populations, but multi-dimensional engagement data has thus far not been widely used in practice. In addition, future studies should record a wide range of demographic data in order to develop a detailed overview of the sample. We suggest the efficacy of future approaches which utilise the engagement construct will hinge on understanding the relative proportionality of PEPs in a target population. This will require larger datasets than presented here in order to help understand the generalisability of the prototypical persona outlined.

4. Large-scale profiling and segmentation using engagement data raises the ethical issue of unwanted or potentially invasive surveillance. We suggest that future young voter engagement research should ensure informed consent and respondent feedback in any study. Such a standard is not only fundamental to preserving ethical conduct, it will also reveal the literacy and willingness of voters to be understood on such terms. 


\section{References}

Alston, M. and Bowles, W. (2007). Research for Social Workers: An Introduction to Methods, London: Routledge.

Banyard, P. \& and Grayson, A. (2017). Introducing Psychological Research. Hampshire, UK: Palgrave MacMillan.

Barrett, M., \& Brunton-Smith, I. (2014). Political and Civic Engagement and Participation: Towards an Integrative Perspective. Journal of Civil Society, 10(1), 5-28.

Berrios, R., Totterdell, P., \& Kellett, S. (2015). Investigating goal conflict as a source of mixed emotions. Cognition and Emotion, 29(4), 755-763.Boonen, J., Meeusen, C., \& Quintelier, E. (2014). The link between social attitudes and voting propensities: Attitude-vote consistency among adolescents in Belgium. Journal of Electoral Studies, 36, 81-93

Bowden, J.L.H. (2009). The process of customer engagement: A conceptual framework. Journal of Marketing Theory and Practice, 17(1), 63-74.

Bowden, J.L.H., Conduit, J., Hollebeek, L.D., Luoma-aho, V., \& Solem B.A. (2017). Engagement valence duality and spillover effects in online brand communities. Journal of Service Theory and Practice, 27(4), 877-897.

Brodie, R.J., Hollebeek, L., Juric, B., \& Ilic, A. (2011). Customer engagement: conceptual domain, fundamental propositions and implications for research. Journal of Service Research, 14(3), 252-271.

Brodie, R.J., Ilic, A., Juric, B., \& Hollebeek, L.D. (2013). Consumer Engagement in a Virtual Brand Community: An Exploratory Analysis. Journal of Business Research, 66(1), 105-114.

Bromley, C., Curtice, J., \& Seyd, B. (2001). Political Engagement, Trust and Constitutional Reform. British Social Attitudes: the 18th Report-Public Policy, Social Ties, London: Sage.

Bulearca, M., \& Bulearca, S. (2010). Twitter: a viable marketing tool for SMEs?. Global Business and Management Research, 2(4), 296-309.

Charles, G. 2009. Conservative Party targets young voters with Spotify ad campaign. PRWeek (Online). Accessed $18^{\text {th }}$ October 2009. Available from World Wide Web: http://www.prweek.com/uk/news/946201/Conservative-Party-targets-younger-voters-spotifyad-campaign/?DCMP=ILC-SEARCH

Clarke, H.D., Goodwin, M., \& Whiteley, P. (2017). Why Britain Voted to Leave the European Union, Cambridge University Press, Cambridge UK.

Conway, M. (2014). Ethical issues in using Twitter for public health surveillance and research: developing a taxonomy of ethical concepts from the research literature. Journal of medical Internet research, 16 (12), e290.

Creswell, J. W. (2014). A Concise Introduction to Mix Methods Research. London: Sage Publications Ltd.

De Vreese, C.H. (2005). The spiral of cynicism reconsidered. European Journal of Communication, 20(3), 283-301. 
Dermody, J., \& Hanmer-Lloyd, S. (2004). Segmenting youth voting behaviour through trusting-distrusting relationships: a conceptual approach. International Journal of Nonprofit and Voluntary Sector Marketing, 9(3), 202-217.

Dermody, J., Hanmer-Lloyd, S., \& Scullion, R. (2010). Young people and voting behaviour: alienated youth and (or) an interested and critical citizenry? European Journal of Marketing, 44(3-4), 421-43.

Dessart, L., Veloutsou, C., \& Morgan-Thomas, A. (2015). Consumer engagement in online brand communities: a social media perspective. Journal of Product \& Brand Management, 24(1), 28-42.

Dessart, L., Veloutsou, C., \& Morgan-Thomas, A. (2016). Capturing consumer engagement: duality, dimensionality and measurement. Journal of Marketing Management, 32(5-6), 399426.

Ekman, J., \& Amna, E. (2012). Political Participation and Civic Engagement: Towards a New Typology. Journal of Human Affairs, 22, 283-300.

Fetters, M.D., Curry, L. A., and Creswell, J. W. (2013). Achieving Integration in Mix Methods Designs - Principles and Practices. Health Services Research, 48(6), 2134-2156.

Fieldhouse, E., Trammer, M., \& Russel, A., (2007). Something about young people or something about elections? Electoral participation of young people in Europe: evidence from a multilevel analysis of the European Social Survey. European Journal of Political Research, 46(86), 797-822.

Fischer, E., \& Reuber, A. R. (2011). Social interaction via new social media:(How) can interactions on Twitter affect effectual thinking and behavior?. Journal of business venturing, 26(1), 1-18.

Gibson, R., \& Cantijoch, M. (2013). Conceptualising and Measuring Participation in the Age of the Internet: Is Online Political Engagement Really Different to Offline? The Journal of Politics, 75(3), 701-716.

Gorecki, M.A. (2013). Electoral context, habit-formation and voter turnout. Electoral Studies, $32,140-152$.

Gummerus, J., Liljander, V., Weman, E., \& Pihlstrom, M. (2012). Customer engagement in a Facebook brand community. Management Research Review, 35(9), 857-877.

Harris, P., \& Lock, A. (2010). Mind the gap: the rise of political marketing and a perspective on its future agenda. European Journal of Marketing, 44(3/4), 297-307.

Henn, M., Weinstein, M., \& Wring, D., (2002). A generation apart? Youth and political participation in Britain. The British Journal of Politics \& International Relations 4, 167-192.

Henn, M., Weinstein, M., \& Forrest, S., (2005). Uninterested youth? Young people's attitudes towards party politics in Britain. Political Studies, 53, 556-578.

Henneberg, S.C., \& O’Shaughnessy, N.J. (2007). Theory and Concept Development in Political Marketing. Journal of Political Marketing, 6(2), 5-31.

Hollebeek, L. (2011). Demystifying customer brand engagement: Exploring the loyalty nexus. Journal of Marketing Management, 27(7-8), 785-807. 
Hollebeek, L., Glynn, M.S., \& Brodie, R.J. (2014). Consumer brand engagement in social media: conceptualisation, scale development and validation. Journal of Interactive Marketing, 28(2), 149-165.

Hudson, J.M. and Bruckman, A., (2004). "Go away": participant objections to being studied and the ethics of chatroom research. The Information Society, 20(2), 127-139.

Hughes, A., \& Dann, S. (2009). Political Marketing and Stakeholder Engagement. Journal of Marketing Theory, 9(2), 243-256.

Ikeda, K., Kobayashi, T., \& Hoshimoto, M. (2008). Does political participation make a difference? The relationship between political choice, civic engagement and political efficacy. Journal of Electoral Studies, 27(2008), 77-88.

Koc-Michalska, K., \& Lilleker, D. (2017). Digital Politics: Mobilisation, Engagement and Participation. Journal of Political Communication, 34(1), 1-5.

Kozinets, R. (2002) The field behind the screen: using netnography for marketing research in online communities, Journal of Consumer Research, 39(1), 61-72.

Lilleker, D., \& Koc-Michalska, K. (2017). What Drives Political Participation? Motivations and Mobilization in a Digital Age. Journal of Political Communication, 34(1), 21-43.

Macnamara, J., Sakinofsky, P., \& Beattie, J. (2012). E-electoral Engagement: How Governments Use Social Media to Engage Voters. Australian Journal of Political Science, 47(4), 623-639.

Mann, C.B., \& Mayhew, G. (2015). Voter Mobilisation Meets E-Government: Turnout and Voting by Mail from Online or Paper Ballot Request. Journal of Political Marketing, 14(4), 352-380.

Mollen, A., \& Wilson, H. (2010). Engagement, telepresence and interactivity in online consumer experience: Reconciling scholastic and managerial perspectives. Journal of Business Research, 63(9-10), 919-925.

Needham, C., \& Smith, G. (2015). Introduction: Political Branding. Journal of Political Marketing, 14, 1-6.

Nickerson, D.W. (2006). Hunting the Elusive Young Voter. Journal of Political Marketing, 5(3), 47-69.

Nielsen, S.W. (2016). Measuring Political Brands: An Art and a Science of Mapping the Mind. Journal of Political Marketing, 15(1), 70-95.

Nulty, P., Theocharis, Y., Popa, S. A., Parnet, O. (2016). Social media and political communication in the 2014 elections to the European Parliament. Journal of Electoral Studies, 44(2016), 429-444.

Nunan, D. and Yenicioglu, B., 2013. Informed, uninformed and participative consent in social media research. International Journal of Market Research, 55(6), 791-808.

O'Cass, A. (2001). An investigation of the political marketing concept and political market orientation in Australian parties. European Journal of Marketing, 35(9/10), 1003-1025. 
O'Cass, A., \& Voola, R., (2011). Explications of political market orientation and political brand orientation using the resource-based view of the political party. Journal of Marketing Management, 27(5-6), 627-645.

Ormrod, R.P., \& Henneberg, C.M., (2011). Political market orientation and strategic party postures in Danish political parties. European Journal of Marketing, 45(6), 852-881.

O'Shaughnessy, N.J., and Henneberg, S.C., (2007). The selling of the President 2004: a marketing perspective. Journal of Public Affairs, 7, 249-268.

Pinkleton, B.E., \& Austin, E.W. (2002). Exploring relationships among media use and political disaffection to political efficacy and voting behaviour. Mass Communication and Society, 5, 113-140.

Poorrezaei, M. (2016). Customer Engagement: Conceptualisation, Validation and Measurement. PhD. University of Salford.

Quinlan, S., Shepard, M., \& Paterson, L. (2015). Online discussion and the 2014 Scottish independence referendum: Flaming keyboards or forums for deliberation. Journal of Electoral Studies, 38(2015), 192-205.

Saunders, M. Lewis, P. and Thornhill, A. (2007). Research Methods for Business Students, Essex: Pearson Professional Ltd.

Sashi, C.M. (2012). Customer engagement, buyer-seller relationships, and social media. Management Decision, 50(2), 253-272.

Schivinski, B., Christodoulides, G. and Dabrowski, D. (2016), Measuring consumers' engagement with brand-related social-media content: development and validation of a scale that identifies levels of social-media engagement with brands, Journal of Advertising Research, Vol. 56 No. 1, pp. 64-80

Smith, G., and Speed, R., (2011). Cultural branding and political marketing: An exploratory analysis. Journal of Marketing Management, 27(13-14), 1304-1321.

Speed, R., Butler, P., \& Collins, N. (2015). Human branding in political marketing: Applying contemporary branding thoughts to political parties and their leaders. Journal of Political Marketing, 14(1-2), 129-151.

Thananithichot, S. (2012). Political engagement and participation of Thai citizens: the ruralurban-disparity. Contemporary Politics, 18(1), 87-108.

Thelwall, M., \& Buckley, K. (2013). Topic-based sentiment analysis for the social web: The role of mood and issue-related words. Journal of the Association for Information Science and Technology, 64(8), 1608-1617.

Thelwall, M., Buckley, K., Paltoglou, G., Cai, D., \& Kappas, A. (2010). Sentiment strength detection in short informal text. Journal of the Association for Information Science and Technology, 61(12), 2544-2558.

Van Doorn, J., Lemon, K.N., Mittal, V., Nass, S., Pick, D., Pirner, P., \& Verhoef, P.C. (2010). Customer engagement behavior: Theoretical foundations and research directions. Journal of Service Research, 13(3), 253-266.

Wagner, M., Johann, D. \& Kritzinger, S. (2012). Voting at 16: Turnout and the quality of vote choice. Journal of Electoral Studies, 13(2), 372-383. 
Zikmund, W.G., 2003. Business Research Methods, USA: Thomson Learning South-Western. 